\title{
The Effectiveness of the New Student's Welcoming Event Using the Volunteerism Approach at the University Level
}

\author{
Al Amin Mohamed Sultan ${ }^{1,4, *}$ Muhamad Amirul Razali ${ }^{2,4}$ Mohammad Rafi Omar ${ }^{3,4}$ \\ Shahrom Mohd Said ${ }^{4}$, NurulFajar Abd Manap ${ }^{4,5}$ \\ ${ }^{1}$ Centre of Smart System and Innovative Design (CoSSID), Fakulti Kejuruteraan Pembuatan, Universiti Teknikal \\ Malaysia Melaka (UTeM), 76100, Hang Tuah Jaya, Melaka, Malaysia. \\ ${ }^{2}$ Pejabat Penasihat Undang-Undang, Universiti Teknikal Malaysia Melaka (UTeM), 76100, Hang Tuah Jaya, Melaka, \\ Malaysia \\ ${ }^{3}$ Fakulti Teknologi Kejuruteraan Mekanikal dan Pembuatan (FTKMP), Universiti Teknikal Malaysia Melaka, 76100, \\ Hang Tuah Jaya, Melaka, Malaysia \\ ${ }^{4}$ Pejabat Timbalan Naib Canselor Hal Ehwal Pelajar (HEP), Universiti Teknikal Malaysia Melaka, 76100, Hang Tuah \\ Jaya, Melaka, Malaysia \\ ${ }^{5}$ Fakulti Kejuruteran Elektronik dan Kejuruteraan Komputer, Universiti Teknikal Malaysia Melaka, 76100, Hang Tuah \\ Jaya, Melaka, Malaysia \\ *Corresponding author. Email: alamin@utem.edu.my
}

\begin{abstract}
Every year the universities would receive the enrolment of new students as a part of the standard cycle of the higher learning education provider's supply chain. As a strategic countermeasure to control the internal traffic during the registration day at the Universiti Teknikal Malaysia Melaka (UTeM), the new students would not be allowed to use their own transportation to the student halls instead the shuttle bus services were provided by the university to transport them after the registration. Taking the consideration of the family members who accompanied them, the stuffs and the travelling fatigue, it would make them felt unpleasant. This may lead to a bad impression towards the university at the very beginning of their campus life. Thus, the university's management via the Student Affairs Office has arranged a group of senior students to assist the students and families on that day on the volunteerism basis. Their roles are to welcome, greet and help the new students during their registration at the university's student halls. This study would assess the effectiveness of this newly designed program by analyzing the volunteerism model from the volunteers' point of view and the second approach was to assess the feedback of the program from the new students' perspectives as well. Two set of questionnaires were devised targeting both groups of volunteers and new intake-students to gain the data before the descriptive analysis is carried out. The results show that the volunteers played a vital role in giving first good impression to the new students and their families while the new students also accept that the volunteers had really helped them where $96 \%$ and $77 \%$ of both groups concluded the event was a success, respectively. The suggestion for the further improvements also is identified which could be taken as an output for the future events.
\end{abstract}

Keywords: Volunteerism, University Student, New Intake, Strategic Management, Satisfaction

\section{INTRODUCTION}

Higher learning education is developing well in Malaysia where many universities; be it public universities or private universities, polytechnic and other educational institutions competing with each other in a positive manner to educate the students who enter these educational institutions which later can contribute to the development of the nation. In order for each educational institution to sustain and be relevant in this industry, they really have to put their utmost care for their main client, which is the student itself. Every year each educational institution would receive the enrolment of new students as a part of the standard cycle of higher learning education provider's supply chain.

This event would embark many opportunities to develop the skills either to their existing or new students in many aspects. However, with thousand numbers of students registering for the new intake at one time, these educational institutions will become congested with lots of people and vehicles, thus a proper plan should be developed as to welcome these new students in a smooth 
way. Taking Universiti Teknikal Malaysia Melaka (UTeM) as an example of the case study, there were 2689 students registered for this new academic semester intake including 505 Diploma students who have registered a bit earlier on April this year. From this number, 2184 students registered during the dedicated registration day at the university's main campus. After the enrolments, the students will register at the student residential colleges. There were six (6) residential colleges, which can accommodate these numbers of students as shown in Figure 1.

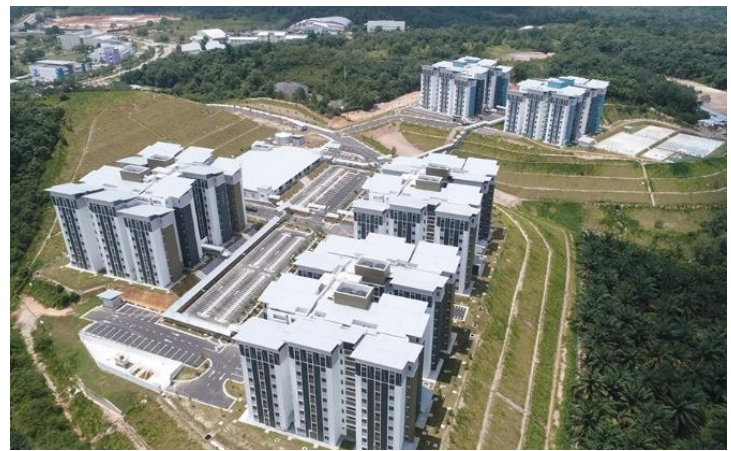

(a)

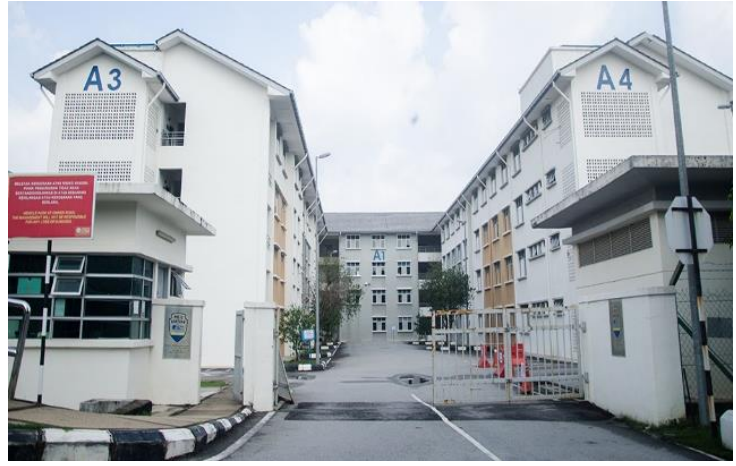

(b)

Figure 1 (a) Five blocks of Satria's Residential Colleges and (b) Lestari Residential College of UTeM

There are five blocks of student residential colleges at Kolej Kediaman Satria namely Satria Tuah, Satria Jebat, Satria Lekir, Satria Lekiu, and Satria Kasturi, while another residential college is Lestari situated one kilometer from Satria. The details of each college's capacity were tabulated in Table 1 . The average were 1000 students per residential college and the accommodation for the disabled students are only available at the two colleges (i.e Tuah and Lekir)

In order to accommodate 2184 newly-registered students, it would cause severe internal traffic from the registration place (Dewan Canselor) to the student residential college. Considering the limited space that was inconvenient for the student's family to drive-wait-unload stuffs, the university set a new approach where the students and family were not allowed to drive to the residential college after the registration. Instead, all the movements of parents and students during the day were catered by the university's shuttle bus services.

\section{Table 1 UTeM's Student Residential Colleges} Information

\begin{tabular}{|c|c|c|c|}
\hline $\begin{array}{c}\text { Residential } \\
\text { College }\end{array}$ & $\begin{array}{c}\text { No of } \\
\text { registered } \\
\text { student }\end{array}$ & $\begin{array}{c}\text { Maximum } \\
\text { Capacity }\end{array}$ & $\begin{array}{c}\text { Accommodation } \\
\text { for disabled } \\
\text { Student }\end{array}$ \\
\hline Lestari & 432 & 1020 & No \\
\hline Satria Jebat & 438 & 1000 & No \\
\hline $\begin{array}{c}\text { Satria } \\
\text { Kasturi }\end{array}$ & 478 & 1000 & No \\
\hline Satria Lekir & 300 & 1000 & Yes \\
\hline Satria Lekiu & 417 & 1000 & No \\
\hline Satria Tuah & 119 & 1000 & Yes \\
\hline Total & 2184 & 6020 & \\
\hline
\end{tabular}

As shown in Figure 2, the distances from Dewan Canselor to Satria Residential Colleges and Lestari Residential colleges are $1.5 \mathrm{~km}$ and $1.6 \mathrm{~km}$, respectively. It will take about 5 minutes driving by car to both colleges from the registration place. This would gave reluctance to the new students and family as they brought their hand luggage and other personal belongings, coupled with the long day travelling fatigue after the registration. In some cases, there were elderly who accompanied the students but they had a difficulty to walk to certain distances. Although the shuttle bus services were provided, this situation was believed to make the students and families felt unpleasant. As it is their first day at the campus, there is a strong need from the university side to reflect some efforts to sustain the positive vibration and to avoid the bad impression at the first glance from the students' point of view.

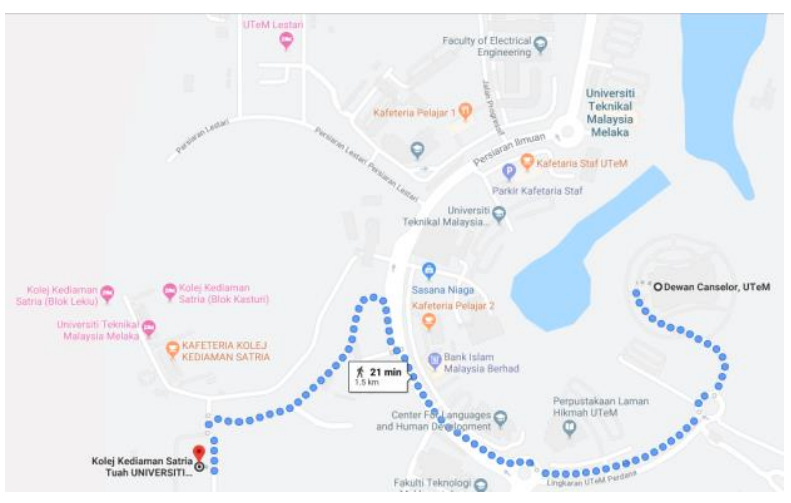

Figure 2 The location and distance of the student residential from registration hall 
Taking this into a consideration, UTeM management via the Student Affairs Office had arranged a group of senior students to assist the new students and family at the student residential colleges on the volunteerism basis during the day of registration. The volunteers' roles are to welcome, greet, assist and provide some self-made refreshment for the new students and parents. This study will assess the effectiveness of this newly designed program to avoid the bad impression at the first day at university to the new students by analyzing the volunteerism model from the point of view of the volunteers and also from the view of the new students. The findings would be used to determine the success of the event and to provide suggestions for the future volunteerism-based university events.

\section{LITERATURE REVIEW}

Volunteerism promotes a positive culture within a society and it is invaluable where it benefits not only the society as a whole but specifically to the organization and to the volunteers themselves [8]. Many attractive methods used including campaign and advertisement to attract people to contribute in volunteerism [12]. Although volunteerism equates free choice, but people sometimes can feel obliged to volunteer. In this section, some important points were discussed such as the concept of volunteerism, criteria of volunteerism, benefit of volunteerism and the effectiveness of an event through volunteerism approach [3]. In a university where the enrolment of new students is considered as a big event, it is vital to conduct a study how to ease the process of such enrolment through volunteerism approach.

\subsection{Concept of Volunteerism}

The spirit of volunteerism for the teenagers of different races is indeed encouraged by the government as this matter reflects the self-value and spirit as a responsible citizen [10]. The spirit and commitment of volunteerism is really appreciated by society as it shares the meaning of humanity and support. A different group of people can contribute towards volunteerism; however, youth community plays a rather bigger role in doing it towards the success of various programs and activities where the students of universities are parts of such youth community. These volunteers; some of them are perhaps choose to be unknown or may be given right amount of publicity would create a great ecosystem by helping the society in need. The spirit of volunteerism is one of the core values that must exist among the younger generation as these will determine the progress or decline of a nation [11]. From the Islamic religion point of view, the guidance in promoting volunteerism nature and value is provided. A reference can be made to a phrase in the Al-Quran "They believe in Allah and the Last Day, and they enjoin what is right and forbid what is wrong and hasten to good deeds. And those are among the righteous" (Al-Imran: 114). Wilson [11] on the other hands gave the definition of voluntary as "any activity in which time is given freely to benefit another person, group or cause". Meanwhile, Musick and Wilson [6] mention that volunteerism as a concept of voluntary work or service which the person contributes without any compulsion, with a sincere intention without having any expectation of material rewards. Therefore, through the understanding of this concept of volunteerism, the students of universities should be a part of community which can create a great ecosystem together with other stakeholders in the society, even more with the excellent intellectual capacity as a university student, many good changes can be done in their own university specifically or Malaysia as a whole, generally.

\subsection{Criteria of Volunteerism}

The concept of volunteerism has been explained before. However, the question arises as whether is it right to conclude the volunteerism as everything is free with no cost at all. Considering the concept and definition of volunteerism, this volunteerism actually shines in a different manner and situation due to different understanding and perception. Something which is considered as volunteerism in one organization is perhaps considered as a work with low minimum amount of salary. However, although there could be many understandings and perceptions of volunteerism, according to Saifuddin [9], there are still three basic criteria which can determine the act of volunteerism. Firstly, the act of volunteerism is not done with the motive to get any financial incentive. However, reimbursement for the expenditure needed and a little amount of token is allowed. Secondly, the act shall be done voluntarily in a way that for example in school where the school organizes a very encouraging community service scheme where it needs the help of students in volunteerism activities. Thirdly, the act shall bring benefit to a community or other people, but not the volunteers themselves. However, it is undeniable sometimes the volunteers themselves will get benefit from the act of volunteerism they done.

\subsection{Benefit of Volunteerism}

Volunteerism as the pure act itself brings many benefits to many stakeholders. The student volunteering has been an integral part of Cardiff's student community activities since the 1960's, and this historical student engagement exists throughout many UK cities [4] . Student Volunteering Cardiff (SVC), a charity run by students who would volunteer in and around the city of Cardiff to 
support vulnerable members of the community was formed in 2001 by the merging of two student led charities set up in the 1960's and has now been running for over 15 years providing substantial support to the Cardiff Community. Many people volunteer with the intention of improving situations or helping people. This is also the same for student volunteers. Through the act of volunteerism, it gives a great opportunity and chance for the students during their time at university to make a big difference to their local community especially within the university context as well as developing their skills of helping. Besides that, the act of volunteerism during university years can also be a route to employment [7]. Through volunteerism, the students can consider which career paths they are more or less well suited due to the huge volunteering opportunities now available in a range of different settings. Apart from that, volunteering also provides a great opportunity and chance to meet people with similar interests and feel part of a community. This similarity shared can create a new connection and good rapport, which eventually will benefit the volunteers in a way that perhaps they do not expect now.

\subsection{Effectiveness of an Event through Volunteerism Approach}

It is indeed many volunteers or people needed to contribute towards the success of an event especially when the event involves a large scale of audiences or participants. Taking into account where many costs will involve if an organization were to pay all people to run an event, the volunteers play a significant role for the effectiveness of such event. Chan Yuen et. el., [1] explain about SKUAD 1 Malaysia. This team has the purposes to help the National Anti-Drugs Agency (AADK) voluntarily to perform the function of prevention, treatment and recovery and eventually for the public welfare. There are many programs of sport, religious and health conducted by SKUAD 1 Malaysia. The effectiveness of this SKUAD 1 Malaysia as a volunteer squad, does not only create an awareness to the society about the dangerous of drug, but rather the act of volunteerism performs by this squad helps and support those who suffered from drugs, being an agent which promotes information about the service of AADK and also to save some costs of drug prevention in a community.

From the above explanation, it can be noted that volunteerism indeed can bring a huge impact to society and bring the effectiveness of the event. The example above and the theory are similarly applicable of its success to many other types of volunteerism acts as it is understood people who volunteer means they are willing to do the job given to them and no element of compel.

\section{METHODOLOGY}

The objectives of this study are to identify the influencingcritical factors in giving good first-impression to the new students by university through a volunteerism-based event and at the same time to assess the success of that event for the Universiti Teknikal Malaysia Melaka (UTeM). This study is to assess the events from the point of views of newly-enrolled students and also the volunteers who involved in the welcoming event. A questionnaire-based survey was selected as the data collection method. A combination of five-point Likert scale questionnaire, multi-choice answers and open-ended questions were developed targeting two different groups of participants. A first group consists of 60 senior students, who registered themselves as the volunteers in charge for the new students' welcoming event. Another set of questionnaire was developed focusing on the new students, about 2320 students registered at the university on the same day that they registered at the student accommodation halls. The questionnaires were devised using the internet-dedicated links that only works for the first-year students and the volunteers, which were sent through the specific channels. The feedback was later assessed and the findings were analyzed via descriptive analysis method that was portrayed in a graphical representation for a better understanding to the reader. The sampling methods were determined using the mathematical calculation for the known population size by Krejcie and Morgan [5] which was strongly referred in the survey related research as in equation (1). The Krejcie and Morgan's sample size calculation was based on $\mathrm{P}=0.05$ where the probability of committing Type I error is less than $5 \%$ or $\mathrm{P}<0.05$ [5].

$$
S=\frac{X^{2} N P(1-P)}{d^{2}(N-1)+X 2 P(1-P)}
$$

where,

$\mathrm{S}=$ required sample size.

$\mathrm{X}^{2}=$ the table value of chi-square for 1 degree of freedom at the desired confidence level $(0.05=3.841)$.

$\mathrm{N}=$ the population size

$\mathrm{P}=$ the population proportion (assumed to be 0.50 since this would provide the maximum sample size)

$\mathrm{d}=$ the degree of accuracy expressed as proportion $(0.05)$.

\section{RESULTS AND FINDINGS}

The findings for both focused groups (i.e. volunteers and new students) were analyzed using a descriptive analysis based on the returned questionnaires. The findings were elaborated together with the response rates and significance of the analyzed data in section 4.1 and 4.2, respectively. The graphical illustrations were also created for better understanding on the specific issues. 


\subsection{Analysis based on the volunteerism- approach}

The questionnaires related to the volunteerism-approach were sent to all 60 respondents. The sample size required for this survey based on equation (1) was 52. However, 53 respondents replied to the survey which indicates the response rate about $90 \%$.

\subsubsection{Students Assignations}

The volunteers in a group of senior students were assigned to six student halls as tabulated in Table 2. The coordination was made by the Principal and fellows at each college and assisted by the Student's Representative Council. The main roles of the volunteers during the student's registration day at the student residential college were to greet them, assist the students and family, and provide the refreshment once they arrived at the college. The refreshments such as cookies and iced-flavor drink were prepared by the volunteers and were offered randomly to the students and families. Each volunteer group was led by a leader and the leader executed the task as planned earlier.

Table 2 The delegations of the volunteers to each residential college.

\begin{tabular}{|c|c|}
\hline $\begin{array}{c}\text { Residential } \\
\text { Colleges }\end{array}$ & $\begin{array}{c}\text { Number of } \\
\text { Volunteers }\end{array}$ \\
\hline Lestari & 10 \\
\hline Satria Jebat & 10 \\
\hline Satria Kasturi & 10 \\
\hline Satria Lekir & 10 \\
\hline Satria Lekiu & 10 \\
\hline Satria Tuah & 10 \\
\hline Total & 60 \\
\hline
\end{tabular}

\subsubsection{Skills enhancement through the volunteerism based event}

The volunteers were involved in various task to assist the new students including having a good interaction and being cheerful although they had to work under pressure and sometimes need a proper delegation of task so the burden could be shared mutually. There were some sort of skills-enhancement took place as these would be the advantages for those involved in the events like this. Figure 3 depicted the type of skills enhancement for the volunteers. These are including the skills enrichment such as Flexibility/Adaptability, Interpersonal skills, problem solving skill, communication skills, teamwork and leadership. From this, the teamwork, communication skills and adaptability skills were identified as having a major impact to the volunteers with $87.5 \%, 75 \%$ and $70 \%$ of level of agreements.

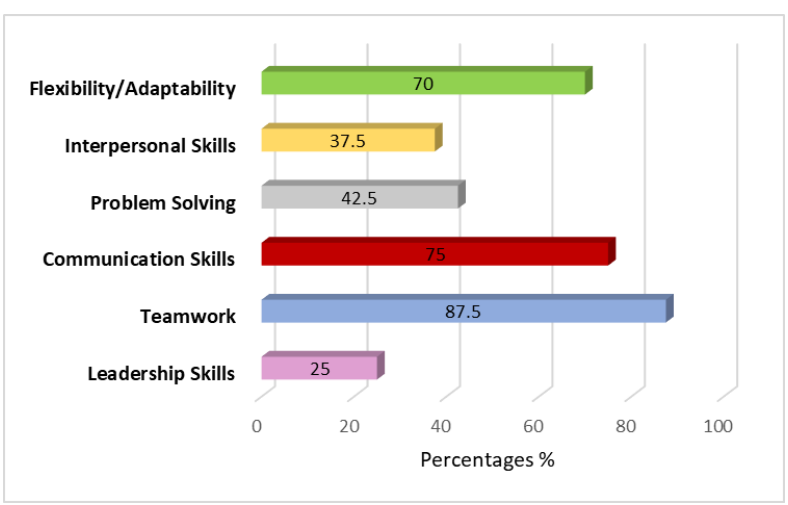

Figure 3 Skills enhancement through volunteerismbased events

\subsubsection{The successfulness of the welcoming event}

The successfulness of the event could be assessed through many parameters, and one of them is via the volunteers involved. The volunteers were the ones that involved directly during the registration day and interacted with the new students and their families. They were in-charged to assist the new students, greet them and offer some refreshments. The response of the students and their family were orally recorded and based on the Figure 4, about $96 \%$ of the volunteers agreed that the event was a strong success. The similar feedback was recorded on the willingness of the volunteers to involve in this kind of activity in the future.

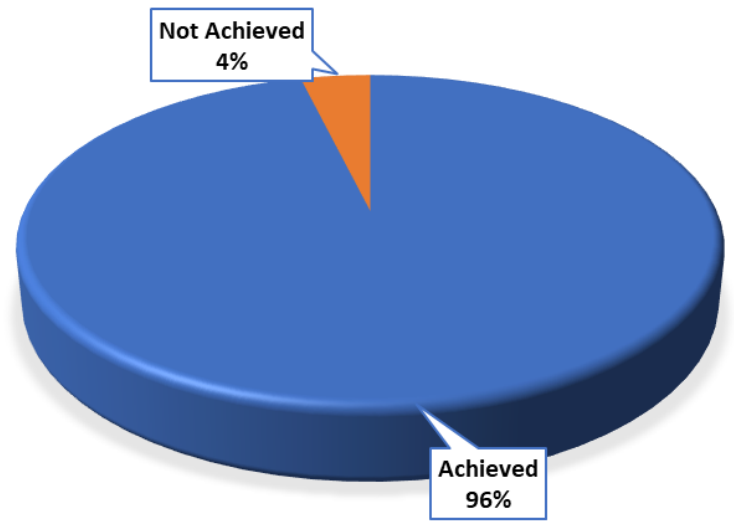

Figure 4 The success or achieved objectives of the welcoming event based on the volunteers perspectives enhancement through volunteerism-based events 


\subsubsection{Suggestion for the future improvements}

Figure 5 illustrates the clustered bar graphs on the improvement factors that were suggested by the volunteers. These factors would be important in executing the event's main concern and worth to be considered such as the welfare of the volunteers, number of the volunteers, the refreshment for the volunteers, number of trolleys and dedicated car park for the parents. Among them, number of trolley and the welfare of the volunteers gained the highest agreement of $40 \%$ and $35 \%$, respectively. The trolley would be significant as the volunteers were utilizing the trolleys to carry the bags and personal belongings of the students. From the survey, it was recorded that $76 \%$ of the new students brought more than three bags each.

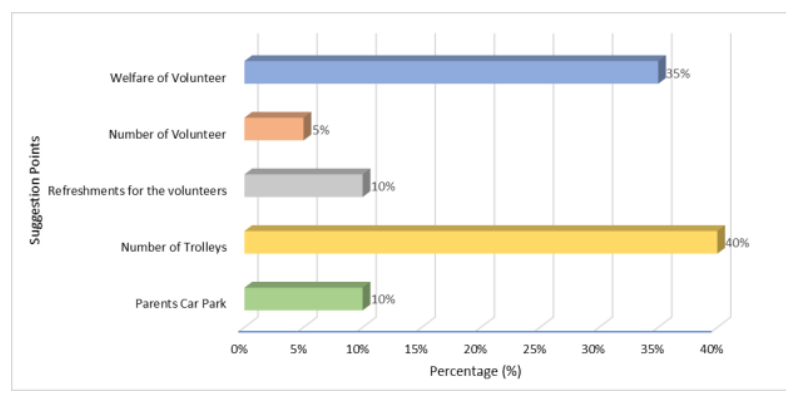

Figure 5 The improvement factors for the future events

\subsection{Analysis based on Newly-Registered Students Feedback}

The questionnaires related to the new student's welcoming event were sent to the all-2184 respondents. The sample size required for this survey based on equation (1) was 324 and the same number of respondents replied to the survey, which indicates the response rate about $15 \%$. Despite the lower response rate, the sampling shows that the data was significant for further analysis given the sampling frame were larger than 500 respondents [2].

\subsubsection{Significance Findings}

There were various information collected, which would be helpful for the university to consider multiple factors associated with them. From the survey, it was recorded that the family members accompanied $97 \%$ of the students during the registration day at UTeM. Most of them left their home for registration on the day of registration (46\%) and a day before $(33 \%)$. Surprisingly, $20 \%$ of the new students left their hometown two to three days earlier to come for the registration while $2 \%$ of them left their hometown five to seven days earlier. The survey feedback also found that $81 \%$ of the students and their family members took the breakfast before coming to the registration at the university.

\subsubsection{The perspectives of important stakeholders during different stages of greeting events}

Figure 6 illustrates the clustered bar graphs on the important findings based on the overall feedback from the students and their families for the conducted welcoming event. There were six stages of perception were analyzed and presented. It can be clearly seen that the bad impression was enacted once the students knew that they were not allowed to drive to the student accommodation halls after the registration with more than $50 \%$ of them felt very disappointed (A0). However, the survey also strongly indicates that this perception was turned into a positive impression through the welcoming event, where $75 \%$ and above of the students and families felt appreciated (A1).

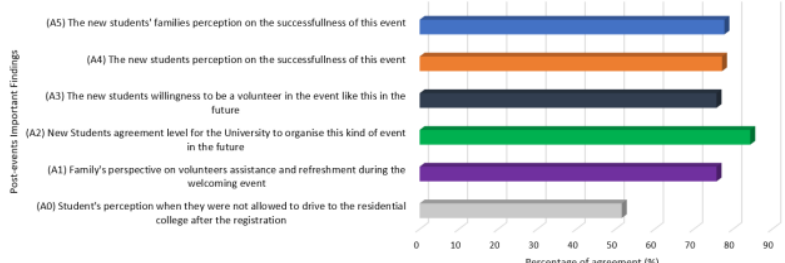

Figure 6 The important findings on the overall perception by the students and their families towards the welcoming event

The new-students were strongly agree for the university to organize this kind of event in the future with the score of $85 \%$ (A2) and more than $75 \%$ of the students were willing to be a volunteer in the future (A3). Both parties (students and their families) agreed that this event was a success for the university with $77 \%$ of the score. This shows that the bad impression was created earlier as believed but later on, it was controlled and changed to positive feelings by organizing this kind of event.

\section{CONCLUSION}

The university management team was expected the bad impression would be created once the new students and their family were not allowed to drive to the student accommodation halls as a solution to control the internal traffic during the day. This bad impression creation was strategically countered through the Student Affair Divisions by organizing the welcoming event to assist the new comers. The volunteerism-based event was introduced involving a group of senior students and it was a big success since the new students had strongly agreed that the volunteers really helped them and their family during the registration day. Both groups with $96 \%$ and $77 \%$ 
agreement level concluded that the event as successful, respectively. The volunteers meanwhile played a vital role in giving first good impression to the new students and their families. Apart from that, the volunteerism-based event was proven to enhance the skills of the volunteers such as communication skills, teamwork, adaptability, interpersonal, problem solving and leadership. The volunteers although doing the job without any financial returns but there is a need to provide some token of appreciation including refreshments by the organizer. The suggestion for the further improvements were also identified which could be taken as an output for the future events.

\section{ACKNOWLEDGMENT}

The authors would like to thank Pejabat Timbalan Naib Canselor HEP and Universiti Teknikal Malaysia Melaka (UTeM) for the financial aid and support.

\section{REFERENCES}

[1] Chan Yuen Fook, Gurnam Kaur Sidhu, Wee Eng Hoe, Mohd. Zaiham Abd. Hamid, Abdul Halim Mohd Hussin, Keberkesanan Program Skuad 1Malaysia Dalam Pencegahan Penyalahgunaan Dadah di Kalangan Klien Berisiko di Komuniti, Jurnal Anti-dadah Malaysia, vol.9, 2019, pp.1-8.

[2] Fosnacht, K., Sarraf, S., Howe, E., Peck, L. K. How important are high response rates for college surveys?. The Review of Higher Education, vol. 40(2), 2017,pp. 245-265.

[3] John Wilson, Noemi Mantovan, Robert Sauer, The economic benefits of volunteering and social class. Social Science Research. vol.85, 2019. Pp.1-11. DOI https://doi.org/10.1016/j.ssresearch.2019.102368

[4] Kathryn Harrington. The benefits of student volunteering. National Council for Voluntary Organizations. London. 2016.

[5] Krejcie, Morgan. Determining Sample Size for Research Activities. Educational and Psychological Measurement, vol. 38, 1970, pp. 607-610.

[6] Musick, M., Wilson, J.Volunteering and depression: The role of psychological and social resources in different age groups. Social Science and Medicine, vol. 56, 2003, pp. 259-269.

[7] Paine, A. E. Volunteering and employability: implications for policy and practice. Voluntary Sector Review, vol. 5, 2014, pp.259.
[8] Pamela Wicker. Volunteerism and volunteer management in sport. Sport Management Review, vol. 20, 2017, pp. 325-337.

[9] Saifuddin, A. Gerakan Kesukarelaan Menjana Perubahan Bermakna. Kuala Lumpur, Majlis Belia Malaysia.

[10] Tuan Pah Rokiah Syed Hussain, Lilah Yasin. Belia dan program kesukarelawan di Malaysia: Satu kajian empirikal, GEOGRAFIA OnlineTM Malaysian Journal of Society and Space, vol.2, 2016, pp.183-194.

[11] Wilson, J. Volunteering. Annual Review of Sociology, vol. 26, 2000, pp.215-240.

[12] Young-JooAhn. Recruitment of volunteers connected with sports mega-events: A case study of the PyeongChang 2018 Olympic and Paralympic Winter Games, Journal of Destination Marketing \& Management, vol. 8, 2017, pp. 194-203 (Eds.), 